\title{
Ecotourism Development and Conservation of the Hundred Islands National Park, Philippines
}

\author{
Christopher J. Cocal \\ Pangasinan State University Alaminos City Campus, Philippines \\ DOI - http://doi.org/10.37502/IJSMR.2021.4708
}

\begin{abstract}
With the Philippines' advantages regarding natural and cultural tourism resources, tourism contributes to the government's inclusive and sustainable socio-economic development agenda. The study focused on the development and conservation of the Hundred Islands National Park (HINP). The descriptive case study research design was used. The respondents of the study were the tourism officers, planning and development officers, and the environment officer of the City of Alaminos. The results revealed that the development projects implemented by the City Government of Alaminos in HINP focused on infrastructure development, transport infrastructure, energy generation and supply, water and waste, tourism promotion, marine resources conservation, and protection. Limited projects and programs were implemented for community development.
\end{abstract}

Keywords: Ecotourism development and conservation, national park, protected areas.

\section{Introduction}

The coastal and marine attractions of the Philippines are well known internationally and have become favorite destinations of tourists, both local and abroad, offering world-class ecotourism products. The Hundred Islands National Park (HINP) in Alaminos City, Pangasinan, Philippines is one of the Philippines' identified coastal and marine destinations with emerging ecotourism potentials (National Ecotourism Development Council, 2002). Ecotourism development and conservation in the HINP, being a national park, is a critical issue.

A marine park is a section of the ocean where a government has placed limits on human activity (National Geographic 2021). It is a piece of land or water that has been declared public property by a national government to preserve and develop for recreational and cultural purposes. It refers to a forest reservation that has been withdrawn from settlement, occupancy, or any other form of exploitation except in accordance with the approved management plan and set aside as such solely to conserve the area or preserve the scenery, natural and historical objects, wild animals and plants, and to provide enjoyment of these features in such areas (Philippine R.A. 7586, 1992). It is essential that parks' activities and infrastructure are environmentally, culturally, and socially compatible with their primary purpose of nature conservation. Tourism developments within national parks may damage the environment.

In 1992, RA 7586 was passed, providing for the establishment and management of a National Integrated Protected Area System (NIPAS). The NIPAS law also provides for the establishment of buffer zones and other multiple-use zones, including ecotourism. Zoning 
recognizes the role of tourism in the protection, development, and management of protected areas. Tourism activities, particularly ecotourism, are permitted in "recreational zones" to provide benefits to residents as well as enable visitors to appreciate the beauty of nature. Along these lines, Department of Tourism (DOT) and Parks and Wildlife Bureau (PAWB) have teamed up to develop a meaningful policy (National Ecotourism Development Council, 2002).

The NIPAS law mandates the establishment of a Protected Area Management Board (PAMB) to plan and administer the protected area, approve implementation proposals and work plans, delineate boundaries, and promulgate rules and regulations for their conservation, protection, and management. RA 9147, the Wildlife Resources Conservation and Protection Act is also a policy consideration for ecotourism activities (National Ecotourism Development Council, 2002).

Anchored on the Tourism Management Plan and Philippine Agenda, a sustainable tourism development framework was prepared by DOT in 1998, providing for ecotourism as a form of tourism that can sustainably use natural and cultural resources while providing employment opportunities for local communities. At that time, collaborations between DOT and other agencies such as the Protected Areas and Wildlife Bureau (PAWB) of Department of Environment and Natural Resources (DENR), the National Commission for Culture (NCC) and the Arts (NCCA), and the National Museum were to be instigated to foster ecotourism (National Ecotourism Strategy, 2002). Building on these initiatives, Executive Order (EO) 111 issued in 1998 provided the basis for a formal partnership between DOT and DENR, and other agencies, to develop and promote ecotourism. EO 111 also established an institutional framework and mechanism for the integrated development of ecotourism. The objectives of EO 111 were furthered by the National Ecotourism Congress in Bohol in 1999 that adopted a national policy and definition of ecotourism (National Ecotourism Development Council, 2002).

The Hundred Islands National Park was established on January 18, 1940, by Presidential Proclamation No. 667, which covered an area of 16.76 square kilometers (6.47 square miles) and was signed by President Manuel L. Quezon for the benefit and enjoyment of the Filipino people (HINP). From Sitio Telbang in the east to Sitio Recudo in the west, the national park, comprising the Lucap Bay and its foreshore regions, was declared a Tourist Zone and Marine Reserve under the jurisdiction and administration of the PTA (Proclamation No. 2183 of 1982). However, parcels of the land reserve for the Marine Fisheries Multi-Purpose Farm (created under Proclamation No. 1282 of June 21, 1974) were withdrawn. They were also placed under the control and supervision of the Tourism Authority for development purposes (Presidential Proclamation No. 2237 enacted on November 6, 1982). In accordance with the Local Government Code of 1991 (RA 7160), Executive Order No. 436 was signed by President Gloria Macapagal-Arroyo on June 21, 2005 transferring the administration, management, maintenance, and operation of the whole Hundred Islands National Park (HINP), including all the activities, facilities and improvements thereafter, from the Philippine Tourism Authority (PTA) to the city government of Alaminos, Pangasinan.

The Department of Environment and Natural Resources (DENR) issued DAO 2008-26, also known as the Revised Implementing Rules and Regulations of RA 7586, which designated Hundred Islands as a natural monument. Reinforcing the proclamation of the HINP as a National Geological Monument, the Management Plan goals and objectives is directed towards the development of the HINP as (1) a model of best practice area for conservation and ecologically balanced domain with the environmentally educated community; (2) a major and 
significant driver for social and economic development; and (3) a showcase of a balanced ecosystem being managed by the Local government of Alaminos City.

The HINP Management Plan specifically attempts to (1) Develop and implement an integrated and community-based program on conservation, protection, and rehabilitation of HINP and other related areas towards sustainable tourism; (2) Increase tourist arrival; (3) Enhance scenic and natural beauty of HINP; (4) Develop alternative tour packages, marketing and promotion strategies; (5) Enhance bird watching tourism and bird-watching related livelihood opportunities; and (5) Increase/strengthen partnerships with various organizations.

Protected areas need tourism and vice versa. Tourism is always an essential component to consider when building and administering protected areas, despite the fact that the relationship is difficult and occasionally opposed (Eagles et al., n.d.).

Ecotourism is defined as environmentally responsible travel to natural places (Tseng et al., 2019), activity that takes place in well-preserved areas for recreation (Noriega et al., 2020), with the responsibility of promoting environmental conservation. Ecotourism is promoted as a long-term activity and tool in and around protected areas, capable of balancing biodiversity protection with local population livelihood (Forje et al., 2021). It has been widely championed by academics and practitioners as a potential contributor of conservation and development (WONDIRAD et al., 2020), an acceptable and sustainable approach to conserve and develop the ecosystem (Do, Kim, Kim, and Joo, 2015).

The sustainable management of ecotourism requires an understanding of the tradeoff between tourism development and environmental conservation(Dushani et al., 2021). However, a lot of sustainable tourism development indicators in national parks are not being implemented and practiced. Indicators that are scientifically defensible, feasible, and valuable in management are rare (Buckley, 2003).

Ecotourism practices environmental preservation by reinforcing stakeholders' sense of responsibility and aims for the distribution of profits in local society through engaging local residents in tourism activities (tourism, operation, management, interpretation) (Choi et al., 2021). Community participation is the causal attribute influencing ecotourism potential and local community support for conservation activities. Cleanliness management; facility management with conservation and the protection of the environment; ecosystem activities based on the natural resources of attraction areas; and collaboration among stakeholders, the government, and local communities to manage ecotourism development influences in ecotourism practices (Tseng et al., 2019). The efficiency of ecotourism in protecting the environment, educating the people, providing recreation, and creating jobs, ecotourism areas are considered essential tourists destinations (Forje et al., 2021). On the other hand, failure to empower and engage communities in poorly resourced and distant areas undermines ecotourism and jeopardizes ecosystems and communities' long-term existence (WONDIRAD et al., 2020).

World Tourism Organization (1997) had proposed 11 core indicators for sustainable tourism development. These include site protection, site stress, use intensity, social impacts, development control, waste management, planning process, critical ecosystem, consumer satisfaction, local satisfaction, and tourism's contribution to the local economy. These indicators provide the means to assess the effectiveness of government policies and actions, 
draw attention to the different areas of the tourism industry that need appropriate management responses (Twining-Ward \& Butler, 2002).

Ecotourism development necessitates comprehensive tourism management, tourist education, and good environmental management (Chen et al., 2020). Tourism and conservation planning is determined by national planning laws and will vary significantly from country to country. The use of national or country park designation is intended to protect the area from development incompatible with primary uses of conservation, recreation, and culture (Sustainable tourism, n.d.). The Department of Tourism's (DOT) National Tourism Development Plan (NTDP) 2011-2016, mandated by Republic Act 9593, provides a framework to guide the DOT and stakeholders in the private and public sectors at the national, regional, and local levels in harnessing the tourism sector's potential as a driver of sustainable growth.

The ecological protection and future growth of maritime parks require a scientific assessment of ecotourism's viability (Chen et al., 2020). The study focused on determining ecotourism development and conservation of the Hundred Islands National Park. The different projects implemented for the development of the HINP were determined.

\section{Methods}

\section{Research Design}

The study is qualitative research with the narrative inquiry as the research design. The design was used since the general objective of the study was to assess ecotourism development and conservation of the Hundred Islands National Park.

\section{Location and Respondents of the Study}

The study was conducted in Alaminos City, Pangasinan, Philippines, the home of the Hundred Islands National Park. Alaminos City, a 5th class city, is located in the northern part of Luzon. One of the youngest cities in the Ilocos Region. It is bounded on the north by the Lingayen Gulf, on the east by the municipality of Sual, on the south by the municipality of Mabini, and on the west by the municipality of Bani. The respondents of the study were the Tourism Officers of Alaminos City, Pangasinan.

\section{Data Gathering}

Before conducting the study, the researcher presented the proposal to the Office of the City Mayor. This was done to inform the city government about the research being conducted. Permission and cooperation were secured by the researcher from the office mentioned above to facilitate the conduct of the study. Pertinent data and documents were requested from the Tourism Office, such as the HINP Management Plan and the programs and projects implemented. The researcher interviewed the Tourism Officers to extract pertinent information about Hundred Islands National Park.

\section{Data Analysis}

The data gathered were analyze using the descriptive data analysis. 


\section{Results}

The management, development, promotion, and conservation of the HINP is under the collaboration of multi-sectors, including different Alaminos City Government Offices, National Agencies, Government and Non-Government Organizations, and the private sector business entity. The management of the HINP is supervised and monitored by the Protected Areas Management Board, led by Department of Environment and Natural Resources (DENR) The Board approves all development plans in the HINP. The Department of Tourism is a member of the PAMB. At the LGU level, the management of the HINP is under the Alaminos City Tourism Office.

Table 1. Agencies and LGU Offices Involved in the Management, Promotion, and Conservation of the Hundred Islands National Park

\begin{tabular}{|c|c|c|}
\hline Area & Office/Agency & Extent of Involvement \\
\hline \multirow[t]{3}{*}{ A. Management } & $\begin{array}{ll}\text { Protected } & \text { Areas } \\
\text { Management Board } & \end{array}$ & $\begin{array}{l}\text { Reviews and approve development } \\
\text { plans }\end{array}$ \\
\hline & DENR & $\begin{array}{l}\text { Leads the PAMB that approves } \\
\text { development plans for the Hundred } \\
\text { Islands National Park }\end{array}$ \\
\hline & $\begin{array}{l}\text { Alaminos City } \text { Tourism } \\
\text { Office }\end{array}$ & $\begin{array}{l}\text { With the PAMB, formulate and } \\
\text { implement the development plan for } \\
\text { the HINP. }\end{array}$ \\
\hline \multirow[t]{3}{*}{$\begin{array}{l}\text { B. Infrastructural } \\
\text { Development }\end{array}$} & Department of Tourism & $\begin{array}{l}\text { Member of the governing board of the } \\
\text { Protected Areas Management Board } \\
\text { that approves infrastructural } \\
\text { development in the HINP }\end{array}$ \\
\hline & $\begin{array}{l}\text { Protected } \\
\text { Management } \\
\text { Board/DENR-Region } 1\end{array}$ & $\begin{array}{l}\text { Approves infrastructural development } \\
\text { through Protected Areas Management } \\
\text { Board Resolution }\end{array}$ \\
\hline & City Engineering Office & $\begin{array}{ll}\text { Monitors } & \text { and implement } \\
\text { infrastructural development in the } \\
\text { HINP }\end{array}$ \\
\hline \multirow[t]{2}{*}{ C. Promotion } & Department of Tourism & $\begin{array}{l}\text { Promote and Market Hundred Islands } \\
\text { National Park as a tourists destination } \\
\text { in the Philippines. } \\
\text { Funded the 42-million-peso road } \\
\text { construction project going to Bolo } \\
\text { Beach }\end{array}$ \\
\hline & $\begin{array}{lll}\text { Alaminos } & \text { City } & \text { Tourism } \\
\text { Office } & & \end{array}$ & $\begin{array}{l}\text { Promote and market Hundred Islands } \\
\text { National Park as a tourist's destination } \\
\text { with the use of social media, live } \\
\text { streaming, and other forms of } \\
\text { promotional activities }\end{array}$ \\
\hline \multirow[t]{3}{*}{ D. Conservation } & $\begin{array}{l}\text { Alaminos City } \text { Tourism } \\
\text { Office }\end{array}$ & $\begin{array}{l}\text { Plans and implement projects and } \\
\text { activities. }\end{array}$ \\
\hline & City Agriculture Office & 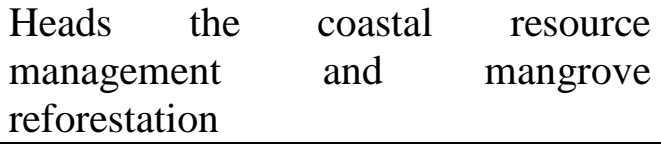 \\
\hline & DENR & \\
\hline
\end{tabular}




\begin{tabular}{|l|l|l|}
\hline & DOST-PCCAARD & $\begin{array}{l}\text { Finance the Coral Reforestation } \\
\text { Project }\end{array}$ \\
\hline & $\begin{array}{l}\text { Other public and private } \\
\text { institutions } \\
\text { organization }\end{array}$ & $\begin{array}{l}\text { Collaborates in the implementation of } \\
\text { various projects. }\end{array}$ \\
\hline
\end{tabular}

Data Source: Alaminos City Tourism Office

The goals of the HINP Management Plan are to enhance the scenic and natural beauty of HINP, develop alternative tour packages, and enhance bird-watching tourism and birdwatching-related livelihood opportunities. To achieve these goals, the Alaminos City Government has conducted development projects in collaboration with various institutions and organizations.

The PAMB approves all infrastructural development in the HINP. Without the approval of the board, no infrastructure will be put up in the HINP. This ensures that the activities and infrastructure in the HINP are environmental, culturally, and socially compatible with their primary purpose of nature conservation. At the LGU level, the City Engineering Office monitors and implements the infrastructural developments in the HINP.

For infrastructural development, the City Government of Alaminos has implemented six projects in the Hundred Islands National Park for ecotourism development. The projects included the construction of 92 gazebos, 19 guest houses, 370 garden lights, 13 stairs and trails with railings, seven pavilions, and four public grilling stations. A total of $\mathrm{PhP114,398,166.01}$ were spent for the infrastructural/facilities development of the HINP. The gazebos and pavilions serve as a shed where tourists can stay when to sun are high. With the guests' houses, tourists can now stay overnight in the HINP. The stairs and railings made hiking much easier and safer for the tourists. These projects have provided greater comfort among the tourists.

To improve the transport infrastructure, the City Government has spent a total of PhP13,521,431.75 on three projects, namely: (1) bridge/docking; (2) floating jetty/docking; and (3) Floating Bridge. The projects also helped in the conservation of corals. Infection among the coral colonies, especially for Porithids and Acropodis, is associated with direct physical destruction due to tourists' trampling the coral heads and anchoring boats. With the bridge docking, trampling of the coral heads is reduced as boats are no longer allowed to anchor anywhere.

Furthermore, the City Government has put up a solar grid system in 14 islands, 44 solar beach lights, and seven powerhouses for energy generation and supply. For water and wastes, 14 anaerobic baffled reactors were constructed amounting to PhP2,444,000.00. These reactors are septic tanks with a filtration process. With this mechanism, water pollution will be reduced. Through these projects, tourists can now conveniently stay in the islands overnight. The longer the tourists stay in the islands, the more income generated by the Alaminos City Government.

For tourism promotion and development, the City Government has invested $\mathrm{PhP} 37,323,211.82$. The projects included the putting up of the station of the cross, erection of the statues of the Virgin Mary and St. Joseph the Carpenter statues. These will attract more Catholic tourists, especially during Holy Week. Three zip lines were put up by the City Government for tourists to have more adventures during their visit to the HINP. Funding for the infrastructure development was derived through LGU funds (IRA and income from the HINP) and a 10-year loan from a bank amounting to PhP63,714,114.50. 
The City Government used the World Wide Web and social media to promote the Hundred Islands National Park. The activities conducted in the City of Alaminos were broadcast through live streaming and Facebook. With this, a more significant number of people around the world were able to know what were happenings in Alaminos City and the developments that took place. This, in turn, contributes to the coming of tourists to visit Hundred Islands' National Park.

Being one of the Philippines' world-class tourist destinations, the HINP is also being promoted by the Department of Tourism. At the LGU level, the promotion of the HINP is being done by the Alaminos City Tourism Office. The promotion was done through Facebook and live-streaming of the different activities in the HINP. The Hundred Islands National Park Festival, which started last 2014, is another way to promote the HINP as a tourist's destination. The Philippine Adventure Consultant, a private business entity has put up some of the new tourists' activities in the HINP. These include helmet diving, banana boating, and snorkeling.

For the conservation of the HINP, the city government, in collaboration with the DOSTPCAARD, Pangasinan State University, Naval Force Northern Luzon - Special Operations Unit, $7^{\text {th }}$ Infantry Division, Phil. Army, and Bureau of Fisheries and Aquatic, the Coral Reforestation Project was implemented. The project aimed to develop technology to enhance the restoration of damaged coral reefs, improve the productivity of coral reef resources for sustainable fisheries, and harness the potentials of underwater tourism by planting 30,000 corals in the protected areas of the HINP. The project also generated technology to enhance the reforestation of damaged corals. The assessment conducted by the Department of Agriculture of the City of Alaminos (the office that directly monitors the project) showed that a $62 \%$ survival rate of live hard coral cover was in good conditions.

The Alaminos City Agriculture Office is in charge of coastal resource management and implemented the Mangrove Reforestation Project. Other agencies, GOs, NGOs, and business organizations are partners in the projects that adopted reforestation areas.

The coastal clean-up is an annual activity being conducted by the City Government of Alaminos, spearheaded by the City Tourism Office in cooperation with the academe (including PSU-Alaminos), non-government organizations (NGOs), national government agencies (NGAs), and civic and non-civic organizations. The City government has also established the Mangrove National Park with a target of 59 hectares. As of December 2015, the total area planted was 42 hectares, or $71 \%$ of the total target area. Of the total area planted with mangrove, 15 hectares were adopted by academe, non-government organizations (NGOs), national government agencies (NGAs), and civic and non-civic organizations. Based on the report of the Department of Agriculture of the City of Alaminos, the project has contributed to the addition of 45.36 metric tons of fish caught per year. The promotion of ecotourism in the Hundred Islands National Park is a tool for conservation and sustainable development.

Peace and order in the Hundred Islands National Park are being maintained by the Philippine National Police and the Bantay Dagat. For community development, the Alaminos City Tourism Office and Alaminos City Cooperative were the responsible LGU offices. The Department of Tourism also provided support through the conduct of training. Likewise, DENR periodically conducts water quality analysis in the major islands visited by tourists. This is done to determine the quality of water to ensure the health safety of the beach-goers. 


\section{Discussion}

The Hundred Islands National Park, adopting the guidelines laid down under the Department Administrative Order No. 2008-26 or the revised IRR of the NIPAS Act, was zoned into two major areas. The areas were the Strict Protection Zone and the Multiple Use Zone. The Strict Protection Zone comprised natural areas with high biodiversity value. The identified areas were closed to all human activities except for scientific studies or ceremonial or religious use. The multiple-use zone is allowed for settlement, traditional, and/or sustainable land use (including agriculture, agroforestry, and other income-generating or livelihood activities). These areas are also where recreational tourism, educational or environmental awareness values are allowed. These are also the areas where installations of national significance/interest, such as the development of renewable energy sources, telecommunication facilities, and electric power lines, are allowed for installation.

Ecotourism practices environmental preservation by reinforcing stakeholders' sense of responsibility and aims to distribute profits in local society through engaging residents in tourism activities (tourism, operation, management, interpretation) (Choi et al., 2021). Community participation is the causal attribute influencing ecotourism potential and local community support for conservation activities. Cleanliness management, facility management with conservation and the protection of the environment, ecosystem activities based on the natural resources of attraction areas, and collaboration among stakeholders, the government, and local communities to manage ecotourism development influences in ecotourism practices (Tseng et al., 2019).

With the City Government of Alaminos playing a key role in developing ecotourism programs, the management and conservation of the Hundred Islands National Park are being collaboratively undertaken by various sectors. The development projects of the City Government of Alaminos are focused on infrastructure development, transport infrastructure, energy generation and supply, water and waste, tourism promotion, and marine resources conservation and protection. It has to be noted that infrastructural development in protected areas such as the construction of roads and trails requires careful planning to allow tourists access to the site they desire, but not to the extent that this is detrimental to habitats and wildlife (Zhou et al., 2013). The infrastructure development can potentially bring adverse effects on the environment, especially on destroying flora and fauna. Thus, it is essential to understand the tradeoff between tourism development and environmental conservation for the sustainable management of the HINP ecotourism (Dushani et al., 2021).

Although the efforts of the City Government of Alaminos, Pangasinan, Philippines, to develop the Hundred Islands National Park as one of the world's ecotourism destinations are anchored on sustainable tourism development and based on national and international guidelines, the findings of the study revealed that limited projects and programs are being implemented for community development. Further, raising the awareness of the people on the need for environmental protection is not part of the development projects of the Tourism Office. It is essential to note that ecotourism sites are regarded as key tourist attractions because of their effectiveness in conserving the environment, educating the public, offering recreation, and creating jobs (Forje et al., 2021). Accordingly, failure to empower and engage communities in poorly resourced and distant areas undermines ecotourism and jeopardizes ecosystems and communities' long-term existence (WONDIRAD et al., 2020). Without the involvement and support of local populations, successful protected area management will be impossible (Mehta, J., \& Heinen as cited by (Lai \& Nepal, 2006). With this, there is a need for 
the Tourism Office of Alaminos City to implement more projects that educates the people and empower the local community.

\section{References}

1) National Ecotourism Development Council (2002). National Ecotourism Strategy.

2) National Geographics (n.d.). Marine Park. Retrieved from https://www.nationalgeographic.org/encyclopedia/marine-park/

3) Republic Act 7586. Retrieved from http://www.gov.ph/1992/06/01/republic-act-no$7586 /$

4) Eagles, P. F. J., Mccool, S. F., Haynes, C. D., \& Phillips, A. (n.d.). Best Practice Protected Area Guidelines Series No. 8 IUCN World Commission on Protected Areas (WCPA) IUCN Programme on Protected Areas Rue Mauverney 28 Sustainable Tourism in Protected Areas Guidelines for Planning and Management Sustainable Tourism in Protected Areas: Guidelines for Planning and Management. www.iucn.org/bookstorewww.wcpa.iucn.org

5) Tseng, M. L., Lin, C., Remen Lin, C. W., Wu, K. J., \& Sriphon, T. (2019). Ecotourism development in Thailand: Community participation leads to the value of attractions using linguistic preferences. Journal of Cleaner Production, 231, 1319-1329. https://doi.org/10.1016/j.jclepro.2019.05.305

6) Noriega, J. A., Zapata-Prisco, C., García, H., Hernández, E., Hernández, J., Martínez, R., Santos-Santos, J. H., Pablo-Cea, J. D., \& Calatayud, J. (2020). Does ecotourism impact biodiversity? An assessment using dung beetles (Coleoptera: Scarabaeinae) as bioindicators in a tropical dry forest natural park. Ecological Indicators, 117. https://doi.org/10.1016/j.ecolind.2020.106580

7) Forje, G. W., Tchamba, M. N., \& Eno-Nku, M. (2021). Determinants of ecotourism development in and around protected areas: The case of Campo Ma'an National Park in Cameroon. Scientific African, 11. https://doi.org/10.1016/j.sciaf.2020.e00663

8) WONDIRAD, A., Tolkach, D., \& King, B. (2020). Stakeholder collaboration as a major factor for sustainable ecotourism development in developing countries. Tourism Management, 78. https://doi.org/10.1016/j.tourman.2019.104024

9) Do, Y., Kim, S. B., Kim, J. Y., \& Joo, G. J. (2015). Wetland-based tourism in South Korea: Who, when, and why. Wetlands Ecology and Management, 23(4), 779e787.

10) Dushani, S. N., Aanesen, M., \& Vondolia, G. K. (2021). Balancing conservation goals and ecotourism development in coastal wetland management in Sri Lanka: A choice experiment. Ocean and Coastal Management, 210. https://doi.org/10.1016/j.ocecoaman.2021.105659

11) Buckley, R. (2003) Ecological indicators of tourist impacts in parks. Journal of Ecotourism. 2: 54-66.

12) Choi, Y. E., Oh, C. O., \& Chon, J. (2021). Applying the resilience principles for sustainable ecotourism development: A case study of the Nakdong Estuary, South Korea. Tourism Management, 83. https://doi.org/10.1016/j.tourman.2020.104237

13) Tseng, M. L., Lin, C., Remen Lin, C. W., Wu, K. J., \& Sriphon, T. (2019). Ecotourism development in Thailand: Community participation leads to the value of attractions using linguistic preferences. Journal of Cleaner Production, 231, 1319-1329. https://doi.org/10.1016/j.jclepro.2019.05.305

14) Forje, G. W., Tchamba, M. N., \& Eno-Nku, M. (2021). Determinants of ecotourism development in and around protected areas: The case of Campo Ma'an National Park in Cameroon. Scientific African, 11. https://doi.org/10.1016/j.sciaf.2020.e00663 
15) WONDIRAD, A., Tolkach, D., \& King, B. (2020). Stakeholder collaboration as a major factor for sustainable ecotourism development in developing countries. Tourism Management, 78. https://doi.org/10.1016/j.tourman.2019.104024

16) World Trade Organization. (1999). Global code of ethics for tourism. Proceedings of Thirteenth session of General Assembly: Santiago, Chile.

17) Twining-Ward, L. \& Butler, R. (2002) Implementing STD on a small island: development and use of sustainable tourism development indicators in Samoa. Journal of Sustainable Tourism. 10: 363-387.

18) Chen, F., Lai, M., \& Huang, H. (2020). Can Marine Park become an ecotourism destination? Evidence from stakeholders' perceptions of the suitability. Ocean and Coastal Management, 196. https://doi.org/10.1016/j.ocecoaman.2020.105307

19) Eagles, P. F. J., Mccool, S. F., Haynes, C. D., \& Phillips, A. (n.d.). Best Practice Protected Area Guidelines Series No. 8 IUCN World Commission on Protected Areas (WCPA) IUCN Programme on Protected Areas Rue Mauverney 28 Sustainable Tourism in Protected Areas Guidelines for Planning and Management Sustainable Tourism in Protected Areas: Guidelines for Planning and Management. www.iucn.org/bookstorewww.wcpa.iucn.org

20) Chen, F., Lai, M., \& Huang, H. (2020). Can Marine Park become an ecotourism destination? Evidence from stakeholders' perceptions of the suitability. Ocean and Coastal Management, 196. https://doi.org/10.1016/j.ocecoaman.2020.105307

21) Choi, Y. E., Oh, C. O., \& Chon, J. (2021). Applying the resilience principles for sustainable ecotourism development: A case study of the Nakdong Estuary, South Korea. Tourism Management, 83. https://doi.org/10.1016/j.tourman.2020.104237

22) Tseng, M. L., Lin, C., Remen Lin, C. W., Wu, K. J., \& Sriphon, T. (2019). Ecotourism development in Thailand: Community participation leads to the value of attractions using linguistic preferences. Journal of Cleaner Production, 231, 1319-1329. https://doi.org/10.1016/j.jclepro.2019.05.305

23) Zhou, Y., Buesching, C. D., Newman, C., Kaneko, Y., Xie, Z., \& Macdonald, D. W. (2013). Balancing the benefits of ecotourism and development: The effects of visitor trail-use on mammals in a Protected Area in rapidly developing China. Biological Conservation, 165, 18-24. https://doi.org/10.1016/j.biocon.2013.05.007

24) Dushani, S. N., Aanesen, M., \& Vondolia, G. K. (2021). Balancing conservation goals and ecotourism development in coastal wetland management in Sri Lanka: A choice experiment. Ocean and Coastal Management, 210. https://doi.org/10.1016/j.ocecoaman.2021.105659

25) Forje, G. W., Tchamba, M. N., \& Eno-Nku, M. (2021). Determinants of ecotourism development in and around protected areas: The case of Campo Ma'an National Park in Cameroon. Scientific African, 11. https://doi.org/10.1016/j.sciaf.2020.e00663

26) Lai, P. H., \& Nepal, S. K. (2006). Local perspectives of ecotourism development in Tawushan Nature Reserve, Taiwan. Tourism Management, 27(6), 1117-1129. https://doi.org/10.1016/j.tourman.2005.11.010 